\title{
SOMATIC EMBRYOGENESIS FROM ZYGOTIC EMBRYOS OF Euterpe oleracea Mart. $^{1}$
}

\author{
ANA DA SILVA LEDO ${ }^{2}$, OSMAR ALVES LAMEIRA ${ }^{3}$, ABDELLATIF KEMALEDDINE BENBADIS ${ }^{4}$, ILMARINA \\ CAMPOS DE MENEZES ${ }^{5}$, MARIA DO SOCORRO PADILHA DE OLIVEIRA ${ }^{6}$, SEBASTIÃO MEDEIROS FILHO ${ }^{7}$
}

\begin{abstract}
The aim of this work was to study the morphogenetic responses of zygotic embryos of açai palm (Euterpe oleracea Mart.) submitted to several conditions of in vitro culture. Several research experiments were conducted, in laboratory, using vegetable material collected from açai palm plants at Embrapa Amazon Oriental, Belém-PA, Brazil. It was possible to verify the expression of a direct, repetitive and no-synchronized model of somatic embryogenesis in mature zygotic embryos cultivated in primary MS medium supplemented with 2,4-D (339.36 $\mu \mathrm{M})$ and transferred to a secondary MS medium in the presence of NAA $(0.537 \mu \mathrm{M})$ and $2 \mathrm{iP}(12.30 \mu \mathrm{M})$. The conversion of somatic embryos into seedlings was reached after 210 days with the transfer of the cultures to a third medium with sucrose and mineral salts concentrations reduced to a half, without growth regulators. Index Terms: açai palm, growth regulators, micropropagation, tissue culture
\end{abstract}

\section{EMBRIOGÊNESE SOMÁTICA EM EMBRIÕES ZIGÓTICOS DE Euterpe oleracea Mart.}

RESUMO- O objetivo do presente trabalho foi estudar as diferentes respostas morfogenéticas de embriões zigóticos de açaizeiro (Euterpe oleracea Mart.) submetidos a várias condições de cultura in vitro. Os experimentos foram conduzidos em laboratório, com material vegetal coletado de plantas de açaí da Embrapa Amazônia Oriental, Belém-PA, Brasil. Foi possível verificar a expressão de um modelo de embriogênese somática direto, repetitivo e assincronizado em embriões zigóticos maduros cultivados em meio primário MS, suplementado com 339,36 $\mu \mathrm{M}$ de 2,4-diclorofenoxiacético (2,4-D), e transferidos para meio secundário MS na presença de 0,537 $\mu \mathrm{M}$ de ácido 1-naftalenoacético (ANA) e 12,30 $\mu \mathrm{M}$ de 2-isopenteniladenina (2iP). A conversão de embriões somáticos em plântulas foi alcançada aos 210 dias da inoculação com a transferência das culturas para um terceiro meio com a concentração de sais e sacarose reduzida pela metade e ausência de reguladores de crescimento.

Termos para Indexação: açaizeiro, regulador de crescimento, micropropagação, cultura de tecidos

\section{INTRODUCTION}

The açai palm (Euterpe oleracea Mart.) stands out among several native species in the Amazon area, due to their different uses and great potential of commercialization of products and co-products, fruits and "palmito" (heart of palm), in both national and international market. However, the use of inadequate propagation techniques and the absence of improved genetic material, have contributed negatively to the rational and economic exploration of this species.

Several reasons were reported for the use of in vitro culture techniques with palm trees, such as the practical aid of the technique for morphogenetic studies and to accelerate programs of genetic improvement. In the case of palm trees, the improvement programs are complex and take too long due to the extended cycle of the species, growth habit and absence of conventional methods of vegetative propagation by the absence of vascular cambium (Tisserat, 1987). In this context, the several techniques of in vitro culture, when integrated in programs of genetic improvement, become valuable instruments for the fast cloning of high genotypes and germoplasm conservation.

Literature and studies that are aimed at making more information on the açai palm in vitro propagation are considerably scant or almost non-existent. The studies have been developed for Cocos nucifera, Phoenix dactilyfera and Elaeis guineensis, due to their great economic impact on the international markets. In general, two basic procedures have been used for palm tissue culture: a) somatic embryogenesis, or direct/indirect organogenesis; and b) reversion of young flower meristems to a vegetative stage (Tisserat, 1987). Guerra \& Handro $(1991,1998)$ obtained success in the direct somatic embryogenesis starting from zygotic embryos and young inflorescences of Euterpe edulis Mart. The objective of the present work was to study the morphogenetic answers of zygotic embryos submitted to several conditions of culture in vitro.

MATERIALANDMETHODS

\section{Explants}

Two kinds of explants were employed: a) mature zygotic embryos excised from mature seeds (wine fruits, ca. $2.17 \mathrm{~g}$ ); b) immature zygotic embryos from immature seeds (green fruits, ca. $1.68 \mathrm{~g}$ ). The fruits were collected in Embrapa Amazon Oriental, Pará State, Brazil. The fruits were washed in running water and immersed in warm water $\left(40^{\circ} \mathrm{C}\right)$. The seeds were submitted to the disinfection procedure in laminate flow camera. The seeds were immersed in ethanol at $70 \%$ for two minutes followed by immersion in solution of sodium hypochloride at $2 \%$ for 20 minutes under agitation and then washed four times in sterile water.

\section{Culture medium}

The zygotic embryos were inoculated in MS medium (Murashige \& Skoog, 1962) supplemented with agar $\left(6 \mathrm{~g} \mathrm{~L}^{-1}\right)$, activated charcoal $(2.5$ $\left.\mathrm{g} \mathrm{L}^{-1}\right)$, sucrose $\left(30 \mathrm{~g} \mathrm{~L}^{-1}\right)$, hydrolysed casein $\left(500 \mathrm{mg} \mathrm{L}^{-1}\right)$ and with different concentrations of 2,4-D (113.12; 226.24; 339.36; 454.48; 565.61; 678.73 $\mu \mathrm{M})$. The $\mathrm{pH}$ was adjusted to 6.0 before autoclave sterilization. The embryogenic cultures induced in the primary medium, were transferred for secondary MS medium with agar $\left(6 \mathrm{~g} \mathrm{~L}^{-1}\right)$, sucrose $\left(30 \mathrm{~g} \mathrm{~L}^{-1}\right)$, in the presence of NAA $(0.537 \mu \mathrm{M})$ combined with $2 \mathrm{iP}(12.30 \mu \mathrm{M})$, aiming to stimulate the progression of the initial phases in order to obtain mature somatic embryos. For the somatic embryo conversion and seedling development, the cultures were transferred for $1 / 2$ MS medium, with agar (6 $\left.\mathrm{g} \mathrm{L}^{-1}\right)$ and sucrose $\left(15 \mathrm{~g} \mathrm{~L}^{-1}\right)$, in the absence of plant growth regulators.

\section{Culture conditions}

In the initial period of 7 days, the cultures were maintained in the dark to prevent browning, under temperature of $26 \pm 2^{\circ} \mathrm{C}$, relative air humidity averaging $70 \%$. After this period the cultures were transferred to a light/dark cycle, $16 / 8 \mathrm{hr}$, photonic flux ca. $52 \mu \mathrm{mol} \cdot \mathrm{m}^{-2} \cdot \mathrm{s}^{-1}$.

\section{RESULTS AND DISCUSSION}

The establishment of viable cultures and their further progres-

1 (Trabalho 078/2002). Recebido: 01/04/2002. Aceito para publicação: 26/09/2002.

Parte da tese de Doutorado do primeiro autor, financiada com recursos da Embrapa Amazônia Oriental/JICA

2 Eng $^{\mathrm{a}}$ Agr $^{\mathrm{a}}$ D.Sc., pesquisadora da Embrapa Acre, caixa postal 392, CEP. 69908-970, Rio Branco-AC, e-mail: analedo@ @ cpatc.embrapa.br

$3 \mathrm{Eng}^{\circ} \mathrm{Agr}^{\circ}$ D.Sc., pesquisador da Embrapa Amazônia Oriental, caixa postal 48, CEP 66017-970, Belém-PA.

$4 \mathrm{Eng}^{\circ} \mathrm{Agr}^{\circ} \mathrm{PhD}$., professor visitante do Departamento de Fitotecnia da UFC, Av. Mister Hull, s/n, CEP. 60020-181, Campus do Pici, Fortaleza-CE.

5 Eng $^{\mathrm{a}}$ Agr ${ }^{\mathrm{a}}$ M.Sc., técnica de nível superior da Embrapa Amazônia Oriental.

6 Eng $^{a}$ Agr $^{a}$ M.Sc., pesquisadora da Embrapa Amazônia Oriental.

7 Eng $^{\circ} \mathrm{Agr}^{\circ}$, D.Sc., professor do Departamento de Fitotecnia da UFC. 
sion occurred in a gelled medium MS containing activated charcoal and 2,4-D. Distinct morphogenetic responses were observed in mature zygotic embryos cultivated in primary MS medium supplemented with several concentrations of 2,4-D, at 80 days in culture (Table 1).

TABLE 1- In vitro responses of cultured mature zygotic embryos of açai palm (Euterpe oleracea Mart.), 80 days after inoculation.

\begin{tabular}{ccccc}
\hline $\begin{array}{c}\text { 2,4-D } \\
(\mathrm{M})\end{array}$ & $\begin{array}{c}\text { Number of } \\
\text { explants } \\
\text { with } \\
\text { response }^{1}\end{array}$ & $\begin{array}{c}\text { \% of } \\
\text { conversion in } \\
\text { normal } \\
\text { seedlings }\end{array}$ & $\begin{array}{c}\text { \% of explants } \\
\text { with granular } \\
\text { structures }^{2}\end{array}$ & $\begin{array}{c}\text { \% of explants with } \\
\text { globular somatic } \\
\text { embryos }^{2}\end{array}$ \\
\hline 113.12 & 36 & 100.0 & 0 & 0 \\
226.24 & 29 & 100.0 & 0 & 0 \\
339.36 & 39 & 0 & 80.43 & 19.57 \\
454.48 & 27 & 0 & 61.42 & 38.58 \\
565.61 & 17 & 0 & 93.41 & 6.59 \\
678.73 & 0 & 0 & 0 & 0 \\
\hline
\end{tabular}

${ }^{1}$ out of total of 45 explants.

$2 \%$ out of the total explants with morphogenetic responses.

When zygotic embryos were cultivated in low concentrations of 2,4-D (113.12 and $226.24 \mu \mathrm{M}$ ), it was observed the progression of germination and the development of normal and vigorous seedlings. However, under high concentrations of 2,4-D (339.36; 454.48 and 565.61 $\mu \mathrm{M})$, it was possible to verify the progressive inhibition of germination and the development of granular structures on the cotyledon node (Figure $1 \mathrm{~A}$ ). After 60 days of cultivation it was observed over these granular structures direct development of globular somatic embryos (Figure 1B). Under these conditions, the matrix tissue produced new embryos at the globular stage in a continuous and no-synchronized way.

There were significant differences between the 2,4-D concentrations and the percentage of mature zygotic embryos with granular structures and globular somatic embryos $(\mathrm{P} \leq 0.01)$. The higher frequency of globular somatic embryos was recorded in culture medium supplemented with 339.36 and $454.48 \mu \mathrm{M} 2,4-\mathrm{D}$ (Figure 2). Similar results were obtained by Guerra \& Handro (1998) in zygotic mature embryos of Euterpe edulis Mart. in initial medium with 226.24-454.48 $\mu \mathrm{M}$ 2,4-D. However Teixeira et al. (1993) observed the callus formation and the absence of embryogenic tissue in mature zygotic embryos of the Elaeis guineensis Jacq. cultivated in Y3 medium (Eeuwens, 1976) with $500 \mu \mathrm{M} 2,4-\mathrm{D}$.
A

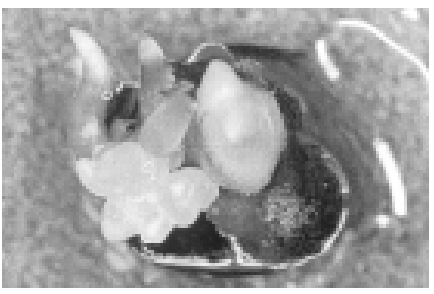

c

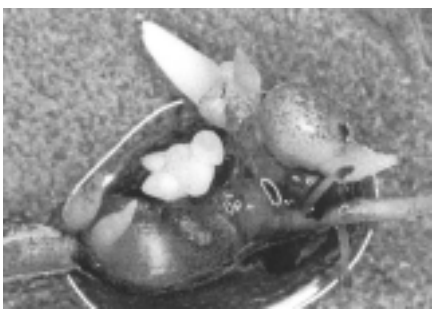

B

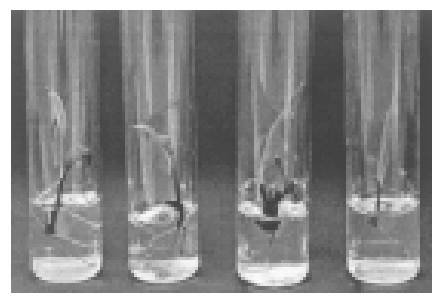

D

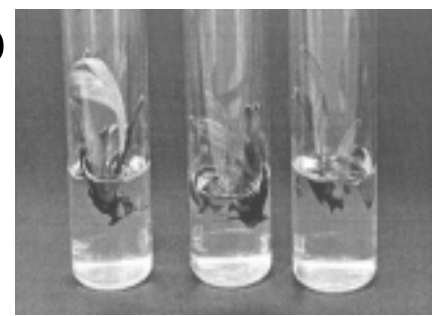

FIGURE 1 - A- Mass of somatic embryos at different development stages (12.5X); B- Formation of somatic embryos under recently regenerated seedling (12.5X); C- Seedlings developed after the isolation of the germinated embryos, after 240 days in culture; D- Proliferation of multiple seedlings.

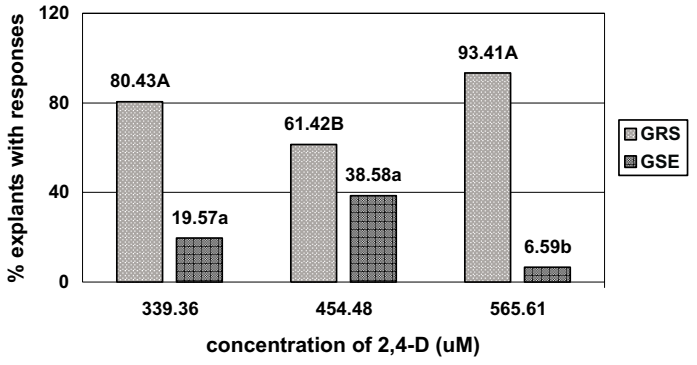

Means followed by the same lower case or capital letters in the same column are not significantly different (Scott \& Knott (1974), 1\%). GRS- $\mathrm{CV}=8.01 \%$; GSE-CV $=36.60 \%$

FIGURE 2 - Percentage of mature zygotic embryos of Euterpe oleracea Mart. with granular structures (GRS) and globular somatic embryos (GSE) under different concentrations of 2,4-D at 80 days after the inoculation.

Thirty five days after the transference of post-globular embryos, cultivated at initial medium with $339.36 \mu \mathrm{M} 2,4-\mathrm{D}$, to the same basal medium free of activated charcoal and supplemented with 12.30 $\mu \mathrm{M} 2 \mathrm{iP}$ and $0.537 \mu \mathrm{M}$ NAA, it was observed the progression to a bipolar developmental stage. Probably the 2,4-D high concentrations in the initial medium inhibited the progression and intensified the phenolic oxidation and the browning in the cultures, decreasing the embryogenetic frequency, number of somatic embryos and embryogenetic efficiency of mature zygotic embryos (Table 2). When the bipolar somatic embryos were transferred to the third medium, with sucrose and mineral salt concentrations reduced to half, and absence of growth regulators, the somatic embryos converted into seedlings (Table 2).

TABLE 2 - Means of embryogenetic frequency (EFR), number of somatic embryos (NSE) and embryogenetic efficiency (EEF) in the secondary medium MS with $0.537 \mu \mathrm{MNAA}$ and 12.30 $\mu \mathrm{M} 2 \mathrm{iP}$ at 150 days after the inoculation and means of embryogenetic frequency (EFR), number of bipolar embryos (NBE) and number of regenerated seedlings (NRS) in the third medium $1 / 2$ MS in the absence of growth regulators at 210 days after inoculation.

\begin{tabular}{cccc}
\hline $\begin{array}{c}\text { Primary medium } \\
(\text { M 2,4-D) }\end{array}$ & $\begin{array}{c}\text { EFR (\%) } \\
(\mathbf{A})\end{array}$ & $\begin{array}{c}\text { NSE } \\
(\mathbf{B})\end{array}$ & $\begin{array}{c}\mathbf{E E F}^{\mathbf{2}} \\
(\mathbf{A ~ X ~ B ) / 1 0 0}\end{array}$ \\
\hline 339.36 & 86.7 & 25.5 & 22.1 \\
454.48 & 60.0 & 12.5 & 7.5 \\
565.61 & 37.7 & 4.8 & 1,8 \\
\hline $\begin{array}{c}\text { Primary medium } \\
\text { ( M 2,4-D) }\end{array}$ & EFR (\%) & NBE & NRS \\
\hline 339.36 & 92.3 & 16.3 & 14.8 \\
\hline 454.48 & 33.3 & 0 & 0 \\
\hline 565.61 & 12.3 & 0 & 0 \\
\hline
\end{tabular}

$1 \%$ of embryogenetic cultures out of the total of explants in the primary medium; ${ }^{2}$ according to GUERRA (1989); ${ }^{3} \%$ of embryogenetic cultures out of the total of explants in the secondary medium.

It was possible to verify that the cultures presented somatic embryos at different development stages (Figure $1 \mathrm{C}$ ) and also, the formation of somatic embryos under the recently regenerated seedlings (Figure 1D). Although the process with mature zygotic embryos had been slower, with seedling production in 240 days, it was observed the proliferation of multiple seedlings. Guerra \& Handro (1998) obtained seedling conversion in immature zygotic embryos of Euterpe edulis Mart. in 180 days.

These results showed that a high frequency, direct, repetitive, no-synchronized and continuous model of somatic embryogenesis can be obtained in cultures of mature zygotic embryos of Euterpe oleracea Mart. The induction and expression of this morphogenetic route was dependent on the developmental stage of the explant and concentration 
of 2,4-D in the primary medium. These results showed that standard procedures suggested by Tisserat (1984a, b), were successfully applied. The morphogenetic responses of immature zygotic embryos were restricted to a germination process with the development of abnormal seedlings (113.12-339.36 $\mu \mathrm{M} 2,4-\mathrm{D})$ and development of granular structures on the cotyledon node (454.48-678.73 $\mu \mathrm{M} 2,4-\mathrm{D})$ without the progression of cultures for subsequent stages (Table 3 ).

The characteristics of this model of somatic embryogenesis of Euterpe oleracea Mart. showed in this work, comprise two important aspects for plant morphogenesis study: a) the induction of an embryogenic program in which the events are modulated leading to the complete regeneration of plants similarly to the development and germination process of zygotic embryo; b) the direct route, without the formation of intermediary callus stage, which prevents eventual anomalies and turns difficult the indirect process. The results obtained by the present work will contribute to research on morphogenesis aspects in palms (initiation, competence and cellular determination) and can be used on improvement programs, mass cloning of elite progenies, inter specific embryos rescue and germoplasm conservation.

TABLE 3 - In vitro responses of cultured immature zygotic embryos of Euterpe oleracea Mart., 80 days after inoculation.

\begin{tabular}{ccccc}
\hline $\begin{array}{c}\text { 2,4-D } \\
(\mathrm{M})\end{array}$ & $\begin{array}{c}\text { Number of } \\
\text { explants }^{\text {with }} \text { response }^{1}\end{array}$ & $\begin{array}{c}\text { \% of } \\
\text { conversion in } \\
\text { normal } \\
\text { seedlings }^{2}\end{array}$ & $\begin{array}{c}\text { \% of explants with } \\
\text { granular structures }\end{array}$ & $\begin{array}{c}\text { \% of explants with } \\
\text { globular somatic } \\
\text { embryos }^{2}\end{array}$ \\
\hline 113.12 & 45 & 31.11 & 6.67 & 0 \\
226.24 & 33 & 0 & 48.49 & 0 \\
339.36 & 14 & 0 & 71,43 & 0 \\
454.48 & 17 & 0 & 100.0 & 0 \\
565.61 & 16 & 0 & 100.0 & 0 \\
678.73 & 08 & 0 & 100.0 & 0 \\
\hline
\end{tabular}

${ }^{1}$ out of the total of 45 explants.

$2 \%$ out of of the total explants with morphogenetic responses.

\section{CONCLUSIONS}

1. The high frequency, direct, repetitive, no-synchronized and continuous model of somatic embryogenesis can be obtained in cultures of mature zygotic embryos of Euterpe oleracea Mart.

2. The induction and expression of this morphogenetic route was dependent on the developmental stage of the explant and concentration of 2,4-D in the primary medium.

\section{REFERENCES}

EEUWENS, C.J. Mineral requirements for growth and callus initiation of tissue explants excised from mature coconut (Cocos nucifera) and date (Phoenix dactylifera) palms cultured in vitro. Physiologia Plantarum, Copenhagen, v.36, n.1, p.23-28, 1976.

GUERRA, M.P.; HANDRO, W. Somatic embryogenesis in tissue cultures. In: AHUJA, M.R.(Ed.) Woody plant biotechnology. New York: Plenun Press, 1991, p.189-196.

GUERRA, M.P.; HANDRO, W. Somatic embryogenesis and plant regeneration in differents organs of Euterpe edulis Mart. (Palmae): control and structural features. Journal of Plant Research, Tokyo, v.111, n.1101, p.65-71, Mar. 1998.

MURASHIGE, T.; SKOOG, F. A. revised medium for rapid growth and bioassays with tobacco tissue cultures. Physiologia Plantarum, Copenhagen, v.15, n.3, p.473-497, Mar. 1962.

SCOTT, A.J.; KNOTT, M. A cluster analysis method for grouping means in the analysis of variance. Biometrics, Raleigh, v.30, n.3, p.507-512, Sept. 1974.

TEIXEIRA, J.B.; SONDAHL, M.R.; KIRBY, E.G. Somatic embryogenesis from immature zygotic embryos of oil palm. Plant Cell, Tissue and Organ Culture, Lisse, Netherlands, v.34, n.3, p. 227-233, Sept. 1993.

TISSERAT, B. Clonal propagation: palms. In: VASIL, I.K. (Ed.) Cell culture and somatic cell genetics of plants. New York: Academic Press, 1984a. v.1, p.74-81.

TISSERAT, B. Date palm. In: SHARP, W.R. (Ed.) Handbook of plant cell culture: crops species. New York: Macmillan, 1984b. v.2, p.505-545.

TISSERAT, B. Palm. In: BONGA, J.M.; DURZAN, D.J. (Ed) Cell and tissue culture in forestry. Dordrecht : Martinus Nijhoff, 1987. p.339-356. 